\title{
Эмоциональное сообщество
}

и повседневная жизнь учителей
Магнитогорска (1929-1941 годы)

Макарова Надежда Николаевна канд. ист. наук, доц., Магнитогорский государственный технический университет им. Г.И.Носова (Магнитогорск, Россия)

Введение. Эпоха форсированной индустриализации была временем ожиданий, осознания новых возможностей и одновременной утраты прежних перспектив. Магнитогорск стал воплощением указанной триады. Ожидания и надежды, возлагавшиеся на крупнейший индустриальный центр как со стороны властей, так и со стороны рядовых строителей светлого будущего, были масштабными. В вопросах реализации амбициозной задачи строительства нового города, в котором живет и трудится новый советский человек, особая роль отводилась профессии учителя. Именно педагогам выпала миссия каждодневно воспитывать поколение подрастающих советских людей, а также вести пропагандистскую работу среди взрослого малограмотного и неграмотного населения города. Учитель должен был быть примером для учеников и их родителей во всем. Именно поэтому советская пропаганда формировала особый образ учителя, а сами учителя стремились в большей или меньшей степени соответствовать ему. В связи с этим крайне актуально выглядит проблема изучения повседневной жизни учительства нового промышленного центра в один из сложнейших периодов советской истории, анализа условий их жизни и труда, возможностей повышения квалификации, реализации учебных задач. Не менее важно 
рассмотрение педагогов общеобразовательных учреждений города Магнитогорска как особой эмоциональной группы, эмоционального сообщества (emotional community), характеризующегося набором устойчивых норм поведения. Вместе с тем не стоит забывать о том, что каждый конкретный учитель принадлежал и к другим эмоциональным сообществам, для которых были характерны иные, порой противоположные эмоциональные нормы.

В данной статье речь пойдет о создании сложного комплекса, включающего базовые понятия «повседневность» и «эмоции», в историческом аспекте. Каждое из этих понятий является перспективным и самодостаточным исследовательским полем, что, однако, не дает повода для отказа от их интегрированного изучения. По справедливой оценке А. Ю. Рожкова, «проблема повседневности в исторической науке, пожалуй, наиболее разработана. Значительно слабее исследован ее эмоциональный аспект, несмотря на то что повседневность и чувственность в действительности тесно переплетены между собой» ${ }^{1}$. Инструментом преодоления дифференцированного изучения «повседневности» и «эмоциональности» может выступать анализ конкретных эмоциональных сообществ в определенных хронологических и территориальных границах. Следовательно, цель данной статьи - изучение эмоционального сообщества учителей города Магнитогорска в 1930-е годы как некой модели взаимодействия «истории повседневности» и «истории эмоций». Хронологические рамки исследования ограничены периодом с 1929 г. (появление первых строителей на стройплощадке) по 1941 г. (начало Великой Отечественной войны, ознаменовавший складывание иной повседневности). В тот период по всему Советскому Союзу осуществлялась форсированная индустриализация, а на территории Магнитогорска разворачивался социальный эксперимент по формированию «нового города» и «нового человека».

В историографии комплекс указанных проблем уже рассматривался, однако вне тесной взаимосвязи элементов. История повседневности в целом, а также жизнь отдельных категорий населения или даже целых городов и регионов советской эпохи становилась объектом внимания историков. Вопросы быта, культуры, образования, досуга, повседневных практик проанализированы в многочисленных работах российских и зарубежных исследователей. Менее изученным в России полем остается эмоциональная сторона жизни населения Советского Союза. Несмотря на то что в последние годы внимание к истории эмоций возрастает ${ }^{2}$, данная проблематика требует особого внимания историков и разработки методологического инструментария. Наконец, учительство как особая социальная группа эпохи сталинизма выступала специальным объектом изучения в исследованиях О. В. Золоторева ${ }^{3}$, Е. И. Васильковской ${ }^{4}$. Е. Юинг анализирует жизнь педагогов 1930-х годов с позиций истории повседневности, обращает внимание на широкий спектр проблем учительского сообщества: от бытовых неурядиц до методик преподавания и дисциплинарных практик. Ключевой вопрос, поставленный автором, касался роли учительства в политических процессах эпохи и того, как учителя эту роль исполняли. В общем виде выводы автора таковы: школьный педагог становится отчасти агентом власти, отчасти жертвой, но главное - беззаветным просветителем ${ }^{5}$. В работе Л. Холмса по 
социальной истории анализируется школьное образование 1920-1930-х годов как социальный институт. Автор уделяет внимание проблеме социальной мобилизации и говорит о «революции снизу» ${ }^{6}$. Интерес вызывают также подходы Ш. Фицпатрик ${ }^{7}$ и Т. О'Коннора ${ }^{8}$ к оценке советской системы образования, которая, по их мнению, представляла результат договора между различными социальными силами. В целом в историографии отражены вопросы государственной политики в области образования, функционирования школы. Вместе с тем в настоящее время отсутствуют исследования, посвященные повседневному существованию учителей как эмоционального сообщества.

Основу источниковой базы исследования составили неопубликованные делопроизводственные материалы городского архива Магнитогорска. В фондах городского совета и отдела образования представлены отчеты, протоколы и стенограммы заседаний педагогических консилиумов города. Воспоминания учителей, оказавшиеся в нашем распоряжении, представляют собой мемуары, написанные по просьбе городского отдела народного образования в 1970-е годы, отредактированные идеологически, но так и не изданные. Можно предположить и наличие самоцензуры в итоговых текстах. Кроме того, воспоминания составлены спустя 20-30 лет после описываемых событий, что также могло повлиять на их содержание. Несмотря на указанные сложности, нарративы предлагают богатейший материал для анализа, а герменевтика чтения между строк и обращение к так называемым случайным проговоркам или случайным деталям могут быть полезными и способствовать выявлению реакций конкретных людей в категориях конкретной эпохи и определенного локального сообщества. Так, анализ воспоминаний педагогов города Магнитогорска позволяет прийти к интересным выводам об особенностях повседневности в городе и эмоциональных проявлениях.

В ходе исследования мы опираемся на термины, введенные в научный оборот У.Редди ${ }^{9}$ («эмотив» представляет собой реальное эмоциональное состояние ${ }^{10}$; «эмоциональный режим» - комплекс эмоций, который служит интеграции и созданию “фундамента любого стабильного политического режима»11) и Б. Розенвейн ${ }^{12}$ («эмоциональное сообщество» - это группа людей, которых объединяют похожие переживания, эмоции, впечатления от каких-либо событий). Под эмоциональным репертуаром принято понимать совокупность эмоциональных проявлений, свойственных определенным индивидам или социальным группам.

Педагогические кадры Магнитогорска. Данные архивов позволяют говорить о том, что учителями работали в основном женщины. Отчеты городского отдела народного образования регулярно фиксировали ситуации, когда в школе работали исключительно женщины и лишь должность директора занимал мужчина. Возраст педагогов города преимущественно был незначительным. Порой педагоги оказывались ровесниками своих учеников ${ }^{13}$. Комплектование кадров осуществлялось по принципу «лишь бы заткнуть дыру» ${ }^{14}$. На протяжении первой половины 1930-х годов в Магнитогорске директорами школ назначали выпускников педагогических техникумов и институтов ${ }^{15}$. Однако с 1933/1934 учебного года кадровые вопросы в системе образования города были поставлены под 
строгий контроль. Отныне при приеме на работу учитывали комплекс социальных (социальное происхождение и возраст) и профессиональных (уровень образования или стаж работы по специальности) качеств будущего работника системы образования. Вопрос подготовки кадров в Магнитогорске играл особую роль в деле реализации учебно-воспитательной работы в школах и дошкольных учреждениях образования. Учителя были необходимы не только для борьбы с неграмотностью, но и для подготовки специалистов, способных работать на металлургическом предприятии. После открытия педагогического института в 1932 г. и педагогического техникума кадровый голод удалось преодолеть. Даже при наличии специализированных образовательных учреждений в городе постоянно работали курсы повышения квалификации и переподготовки. В период с 1932 по 1934 г. такие курсы прошли 160 школьных и 550 дошкольных педагогов ${ }^{16}$. Результатом работы по решению кадровых вопросов в системе образования города стал количественный рост педагогов. Так, педагогический коллектив школ Магнитогорского района возрос со 100 чел. в 1930 г. и 168 чел. в 1931 г. до 562 чел. в 1934 г. ${ }^{17}$ Кадры дошкольных учреждений увеличились с 30 чел. в 1930 г. до 735 чел. в 1934 г. ${ }^{18}$ Наблюдалось изменение и качественных характеристик в среде педагогов. По данным архивов, если в 1932 г. 45,9\% учителей обладали неоконченным высшим образованием, 10,5 \% имели семилетнее образование, 24,5\% - неоконченное среднее, 10,3\% - политехническое, $10 \%$ - высшее профессиональное, то к 1939 г. 18 \% учителей города имели высшее образование ${ }^{19}$.

Ландшафты повседневной жизни. Повседневный ландшафт жизни учителей Магнитостроя на первый взгляд не отличался от жизни иных сообществ города. Эта тенденция легко прослеживается в источниках личного происхождения, в периодической печати и делопроизводственной документации. Общая неустроенность быта, латентный голод, антисанитария первых лет пребывания на Магнитострое коснулись каждого. Во второй половине 1930-х годов условия жизни в городе стали лучше, что проявилось в нормализации снабжения горожан товарами первой необходимости, преодолении эпидемических заболеваний и разрешении острого жилищного кризиса.

Педагоги Магнитогорска, как и другие горожане, испытывали существенные трудности в решении жилищного вопроса. Большинство учителей проживали в бараках комнатного типа. Одна из первых учителей Магнитогорска А. С. Терехова вспоминала: «В июле 1931 г. мы переехали жить в барак Доменного городка. Здесь барак был разгорожен горбылем на комнаты, в одной из которых нас поселили. Обстановку составляли топчаны на козлах, стол из грубых досок, табуретки. В углу стояла печь, которую топили сами. Воду брали из водоколонки и кипятилки, работавших круглые сутки. Постепенно обзаводились имуществом: достали железную кровать, крашеный стол. Таково начало, такова первая поступь на Магнитке» ${ }^{20}$. Даже учителя, приезжавшие по контракту в Магнитогорск и имевшие основания на получение жилплощади в соответствии с трудовым договором, оказывались в бараках ${ }^{21}$. Учитель О.П. Эбулдина отметила: «Барак - новое для меня слово. Где и когда и кем выдумано это слово?! Входишь в барак... длинный, неширокий коридор, в начале и в конце которого 
входные двери, а по бокам двери в жилые комнаты. В каждой комнате живет семья в три-пять человек. Общая для всех кухня... Зимой по коридору гуляет ветер, холодно...»²2 Очень часто педагоги проживали прямо в школах. Это явление было не единичным, носило массовый характер. Для решения жилищного вопроса учителя своими силами строили для себя бараки. Примечателен случай с получением жилья учителем Чертиновской, которая проживала в школе за неимением собственного жилья. «[Чертиновская] указала коммунальному отделу на свободную комнату и просила ордер. Ей предложили взять справку у коменданта... Приносит справку-подтверждение, ей предложили встать в очередь. Чертиновская идет к прокурору, который разрешает вселиться. Но заведующий жилотделом запрещает... комната занята иностранцем. Тогда я [Юдилевич] ${ }^{23}$ предлагаю Чертиновской через две недели хождений понаблюдать - есть ли иностранец, его нет - сбили замок и вселили учителя. Через три дня дали ордер» ${ }^{24}$. Дефицит учителей в Магнитогорске формировал систему льгот и поощрений для сотрудников системы образования. Ключевым преимуществом в сфере жилищного вопроса на местном уровне стало финансирование «обустройства жилого помещения» со стороны городского отдела народного образования ${ }^{25}$. Город формировал также систему льгот в сфере снабжения учителей и работников интеллектуального труда продуктами и товарами первой необходимости. Некоторые ценные специалисты прикреплялись к первой категории снабжения, закрытому распределителю и столовой ${ }^{26}$.

Президиум городского совета неоднократно отмечал необходимость повышения материального благополучия среди педагогов и, как следствие, культурного облика учителей города. Для повышения культурно-бытового уровня среди педагогов был сформирован план увеличения заработной платы в течение двух лет в 2,2 раза. В реальности заработная плата учителей города возросла в 2,4 раза за три года и составила 180 руб. в 1934 г. ${ }^{27}$ Также в Магнитогорске педагоги наравне с рабочими цехов первоочередного значения Магнитогорского металлургического комбината после 1934 г. получили право на внеочередное курортное лечение, бесплатное посещение театра. Для того чтобы оценить реальный размер заработной платы педагогов, укажем цены на некоторые товары. Так, в 1931-1932 гг. ведро картошки стоило около 12 руб., а в 1934 г. - 18 руб. ${ }^{28}$, что составляло 10 \% от зарплаты за месяц учителя. По сравнению с другими специальностями зарплата учителей выглядела не лучшим образом. Например, в 1931 г. зарплата бухгалтера составляла 200-250 руб., уборщик получал 70 руб., а учитель - 75 руб. В 1935 г. зарплаты этих же профессиональных групп составили 375, 150 и 180 руб. соответственно.

Воспоминания первых учителей города Магнитогорска свидетельствуют о трудностях, с которыми столкнулась школа в 1930 г. Так, учителя Турюнеева и Котов рассказывали: «В мае 1930 г. еще ничего не было, кроме улицы на пятом участке и ряда рубленых домов на первом участке. Было два ликпункта, организованных учительницей Пановой в порядке общественной работы... В школе на 13 участке паровое отопление не работало, занимались в шубах» 29 . Подобные свидетельства описывают типичные условия повседневной учебы и работы в образовательных учреждениях Магнитогорска. 
Тезаурус эмотивов в исторических источниках. В текстах воспоминаний широко представлены разнообразные пояснительные эпитеты, характеризующие учителя как человека и профессионала. Весь массив подобных пояснений можно сгруппировать в три блока: 1) характеристики профессиональных качеств учителя; 2) описание общечеловеческих черт; 3) типизация внешнего облика педагога. Ключевые профессиональные характеристики в воспоминаниях были сугубо положительными. Каждый учитель, ставший героем воспоминаний, обладал «глубокими прочными знаниями», «хорошей теоретической и практической подготовкой», «богатым профессиональным опытом», а в учебном процессе царила исключительно «деловая рабочая атмосфера», жизнь была очень активной, насыщенной различными общественными нагрузками. Учитель П.И. Ильяшенко отмечала: «Жизнь в учительской среде била ключом. Вечерами проверяли ученические тетради, готовили наглядные пособия... Я была активным участником всех дел: озеленяла город, ездила на лесозаготовки, занималась ликбезом, была руководителем методического объединения начальных классов, внештатным инспектором горОНО»30.

Несомненно, учебная, воспитательная и общественная нагрузка педагогических работников была чрезвычайно высокой, но жизнь в городе оказывалась намного сложнее, чем патетическое ее описание в мемуарах. В значительной степени профессиональные характеристики учителей города, приведенные в источнике, были идеалистическими, к котором скорее стремились, нежели имели на практике в 1930-е годы. Постепенный рост уровня образования среди педагогов города не являлся свидетельством улучшения образовательного процесса и наличия «деловой атмосферы» в школах. Бытовые трудности приводили к тому, что учителя практически не готовились к урокам. Чаще всего на подготовку у педагогов не хватало времени и сил ${ }^{31}$. Отношение к своим прямым обязанностям у учителей формировалось под воздействием многих обстоятельств (уровень квалификации, возраст и, естественно, индивидуальные черты человека). В Магнитогорске неоднократно были зафиксированы случаи срыва занятий из-за неявки учителя на работу без уважительных причин ${ }^{32}$. «Рабочая атмосфера» в магнитогорских школах, о которой регулярно упоминалось в воспоминаниях как о типичном явлении, свидетельствующем о профессионализме педагогов, также не была тотальной. Отчеты городского отдела народного образования и воспоминания учеников эпохи 1930-х годов говорят о наличии проблем в сфере дисциплины. Переростки, которых заставляли учиться, всевозможными способами пытались срывать уроки. Учителя оказывались в сложной ситуации. Некоторые применяли силу. Респондент Л. Г. Чернопятова рассказывает: «Запомнился мне особенно наш классный руководитель Иван Сергеевич. Не потому, что знания какие-то особые давал, а просто мужчина в школе - редкость, и еще потому что про него рассказывали, что он детей бьет...»33 В целом проблема дисциплины в школе стояла остро. Многие учителя отмечали нежелание детей учиться, делать уроки, хорошо себя вести во время занятий. Учитель Корнилова на одном из партсобраний в 1933 г. отметила: «В школе... кроме матерщины ничего не услышишь» ${ }^{34}$. Проблемы социальнобытового плана также не всегда позволяли осуществлять учебный процесс 
в нормальном режиме. Вместо уроков часто практиковалось решение хозяйственных проблем, связанных с утеплением школьных помещений, уходом за пришкольным огородом и т. п. ${ }^{35}$ Естественно, подобное проведение уроков обусловливалось объективными обстоятельствами.

Общечеловеческие качества педагогов города локализовались вокруг понятий «трудолюбие», «дисциплинированность», «требовательность», «скромность», «честность». Весь массив воспоминаний об учителях 1930-х годов переполнен однокоренными словами и синонимами из указанного ряда. «Трудолюбие» преподносилось как важнейшая ценность в учительской среде и всегда сопровождалось упоминаниями об энергичности, нежелании сидеть на одном месте, участии в общественных мероприятиях различной направленности. «Дисциплинированность» в эмоционально-чувственной сфере восходила к воспитанию самоконтроля, умению контролировать свои эмоции и проявлять их согласно действующему «эмоциональному режиму». Среди волевых качеств личности педагога одним из важнейших была «требовательность», выражавшаяся в способности учителей побудить себя и своих учеников к социально одобряемым действиям, поступкам, эмоциям, а также в возможности запретить асоциальные деяния. Так, в мемуарах педагога Е. К. Яворской есть замечательный сюжет, иллюстрирующий должную требовательность учителя к учащимся, результатом чего стала высокая успеваемость класса и формирование у ребят чувства долга и ответственности: «Мы с завучем вошли в класс. Нас приветствовали свистом... Прямо перед моими глазами мальчики первого ряда сели на столы... Тройка рослых ребят подошла ко мне и сказала, что я работать у них не буду... Плохо видя и слыша классную аудиторию, я назвала свое имя и отчество, сказала, что буду у них учительницей и повела урок арифметики. Только в конце урока заметила, что мальчики первых рядов спустились со столов... все ученики сидели нормально... За первые же два урока ребята сообразили, что им меня не догнать и не перехитрить. Нужно было добиться изменения репутации класса в школьном коллективе... В конце учебного года классу вручили переходящее красное знамя» 36 . “Сромность» трактовалась не только как черта характера, проявляющаяся в умеренности требований, но и как отсутствие стремления к достатку, роскоши, соблюдение рамок приличия. В целом скромность тесно связывалась с дисциплинированностью и также должна была формировать самоконтроль. Наконец, «честность» как человеческая добродетель и моральное качество предполагала правдивость, принципиальность и верность принятым обязательствам. Учителю было стыдно не выполнить взятые на себя обязательства, отказаться от воспитания трудных учеников. Напротив, приветствовались действия педагогов, направленные на реализацию самых сложных задач в деле обучения и воспитания подрастающего поколения.

Несомненно, профессия учителя требовала огромных сил и самоотдачи, но активность педагогов в значительной степени формировалась предлагаемыми социокультурными условиями эпохи индустриализации. О буднях первых магнитогорских учителей свидетельствует график рабочего дня учителя русского языка и литературы О. П. Эбулдиной, сохранившийся в ее воспоминаниях: 
«Подъем в 6 часов утра... Бежим в столовую. Что-то едим... Глотаем горячий чай... Сбор в институт. Дорога (и в грязь, и в дождь, и в снег). Пединститут. 4 дня в неделю лекции. Два дня - читальный зал. Дорога домой. Очередь в столовой. Школа. Ежедневно у меня по шесть уроков. Раньше 9 часов вечера из школы не уходили. В 9 часов школу закрывали. Ужин (готовим сами). Отдых. До 12 часов ночи, а то и позже подготовка к урокам, тетради, готовились к лекциям в институт. Работали с отдельными ребятами, консультации, совещания...» ${ }^{37}$

Внешний облик учителей, согласно воспоминаниям, имел определенные стандарты. Все педагоги обладали «строгими умными глазами» и «стройной, статной фигурой». Даже речевая и двигательная активность, присущая учителю, была особой: «размеренная походка», «негромкая спокойная внушительная речь». В целом облик учителя был привлекательным и достойным подражания.

Официальный дискурс и границы эмоционального сообщества предписывали педагогам использование определенного эмоционального репертуара. Вслед за психологами Полом и Анн Клейнгинна главный редактор «Журнала социальной истории» Питер Стернс ${ }^{38}$ предложил изучать эмоционологию как систему ценностей, относящихся к эмоциям и их восприятию. Педагогическое сообщество, бесспорно, выполняло функцию социализации детей и молодежи, формируя определенные стандарты поведения в обществе. Согласно мнению Е.Т. Юинга, учитель был своего рода агентом власти ${ }^{39}$. Чтобы реализовывать данную функцию, педагог сам должен был демонстрировать должное общественное поведение. Учитель - публичный человек, поэтому его поведение оценивается в первую очередь окружающими его людьми. Так, Г.А.Озерова вспоминала: «Наконец в 1932 г. и мы с мужем переехали работать в Магнитку. Муж Мелентий Алексеевич Озеров был назначен зав. школой № 22 на Центральном поселке, а я учительницей в типовом трехкрылом одноэтажном здании. Поместили нас в учительском бараке. Трудно было приживаться, когда нигде ни дерева, ни кустика. Летом стояла жара, ночи не приносили прохлады. Но вскоре сама обстановка заставила зажить по-новому, по-магнитогорски. Здесь в бараках жизнь каждого была на виду у всех. Комнаты, выходящие в общий коридор, общая кухня, общий умывальник неизбежно вводили людей в соприкосновение, сближали. То же делали столовая, клуб, кипятилка, водозаборная колонка. А с началом учебного года закипела школьная трудовая жизнь - из барака в школу, из школы в барак, совместная подготовка к урокам, совместное изготовление пособий к урокам, коллективные походы в кино, субботники и другие коллективные дела» ${ }^{40}$. Подобная обстановка неизбежно вела и к коллективизации чувств и к соответствию заданному эмоциональному репертуару педагогического сообщества.

Неприемлемыми для учителей выступали эмоции страха, паники, усталости, нетерпеливости, вспыльчивости и т. п. Такие эмоциональные проявления не приветствовались. О негативных эмоциях не упоминалось в мемуарах, предназначенных к опубликованию. А вот в материалах устной истории можно обнаружить указания на маркируемые среди педагогов эмоции. Так, в воспоминаниях О. В. Быстровой о детстве в Магнитогорске отмечалось: «Уроки были скучные... все голодные были - и дети и учителя... Наш классный руководитель 
была всегда уставшая и раздраженная» ${ }^{41}$. В рассказах магнитогорки Л. Г. Чернопятовой о ее школьных годах с приятными воспоминаниями и радостными эмоциями соседствовали сюжеты о «ругани учителей на учеников» и подзатыльниках и оскорблениях в адрес детей ${ }^{42}$. Учитель Магнитогорска, поэтесса Н.Г. Кондратковская в своих мемуарах отметила, что работать приходилось на две ставки до изнеможения ${ }^{43}$. Социально одобряемые эмоции в среде учителей были крайне разнообразными, но в целом сводились к следующим: гордость, патриотизм, тревога, возмущение, радость, энтузиазм. В перечисленном ряду «тревога» и «возмущение» стоят обособленно, так как вне определенного контекста могут оцениваться как отрицательные. Однако подобные эмоциональные реакции возникали в результате негативного, а порой асоциального поведения учеников, низкой успеваемости, прогулов, неблагополучной обстановки в семьях учащихся, отказа родителей участвовать в воспитании своих детей и т. п. Например, как мы уже упомянули выше, Е. К. Яворская с тревогой вошла в класс с неблагополучной репутацией в школе, а возмущение учителя вызвала выходка ребят, севших на столы ${ }^{44}$. Напротив, достижения учащихся формировали чувство гордости и удовлетворения от проделанной работы. Чувство гордости (точнее, эмотив «гордость») стояло на службе официальной пропаганды в Магнитогорске. Периодическая печать, в том числе газеты-листовки и газеты-молнии, официальные представители города и партии регулярно использовали «гордость» на протяжении всего советского периода. В школе «гордость» играла важную роль в процессе воспитания. Не случайно на стендах в рекреациях школ вывешивали портреты лучших учеников под заголовком «Гордость школы». Примеры индивидуальных достижений в учебе или труде формировали должное поведение и даже необходимые эмоции среди населения: «Я горжусь тем, что частица моего труда пошла на пользу коммунистического воспитания нового поколения Магнитогорска, горжусь причастностью к становлению столицы горной металлургии страны»45.

По мнению М. Рольфа и А. фон Климо, содержание эмоции «энтузиазм» заключено в достижении конкретной цели ${ }^{46}$. Согласно официальному дискурсу, именно энтузиазм сопровождал магнитогорцев в труде и отдыхе, дома и на субботниках, в учебе и в соцсоревнованиях и т. д. Власти грамотно применяли эту положительно окрашенную эмоцию, создавая ощущение воодушевления, желание действовать. Использовалась данная эмоция и в педагогическом сообществе. Воспоминания педагогов города пестрят упоминаниями о «работе с энтузиазмом, с задором» ${ }^{47}$. Ключевым результатом энтузиазма учителей, согласно средствам массовой информации, становились успехи учащихся, радость учителю приносили достижения его учеников. В свидетельствах учителей, не предназначенных к опубликованию либо изданных после распада Советского Союза, подчеркивалось, что радость состояла в простом: «...стало полегче. Зарплату добавили... учение закончено, диплом вот-вот будет на руках, работа по душе, дитя подрастает» 4 . «Радость в труде» - еще один классический тезис, характеризовавший эмоциональное сообщество учителей города. В официальном дискурсе часто можно прочесть фразы: «Это был труд, труд большой, но радостный!»49 Действительно, трудовая деятельность, любимая 
работа, карьера могли приносить и приносили радость учителям, однако актуален вопрос о тотальности радости в труде. Обращение к микроуровню текста, выявление «проговорок» позволяет нам говорить о том, что для очень многих педагогов работа была тяжелым бременем: «уроки тянулись», «не школа, а цирк беспризорный», «на работу еле плелась» 50.

Простые радости часто характеризовали представителей еще одного эмоционального сообщества - семьи. В воспоминаниях, подготовленных в 1970-1980-е годы, учителя крайне неохотно повествуют о личной стороне жизни в Магнитогорске 1930-х годов. Хотя у большинства педагогов были семьи, дети, пожилые родители, домашние заботы, эта сторона повседневной жизни педагогического сообщества не освещалась. Здесь показателен рассказ респондента Н. А. Алешниковой о том, как она, будучи ученицей третьего класса, искренне удивилась, встретив свою учительницу в продуктовом магазине. Ребенок свято верил в то, что учитель всегда занят профессиональными обязанностями и продуктами питания не может интересоваться ${ }^{51}$. Советские мемуары лишь иногда и вскользь указывали на то, что дети учителей города добиваются высоких результатов в учебе и труде. Так, учитель А. С. Терехова отметила: «В атмосфере напряженного труда выросли мои девочки. Выучились, все получили высшее образование. Одна стала врачом-акушером, другая инженером, третья и четвертая - учителями» ${ }^{2}$. Отрывок уникален не только тем, что в нем есть отсылка к частной жизни учителя, но и тем, что отношение матери к детям обезличено (дочери названы порядковыми номерами, а не по именам).

Заключение. История слишком сложна, чтобы какое-либо «эмоциональное сообщество» могло быть охарактеризовано каким-то однородным «ландшафтом чувств». Педагогическое сообщество города Магнитогорска не стало исключением. Социально одобряемые и маркируемые эмоции заданного эмоционального режима не были единственными в репертуаре магнитогорских педагогов. Каждый конкретный педагог принадлежал как минимум еще к одному эмоциональному сообществу, в котором наблюдались противоположные профессиональному эмоциональному режиму эмоции. Последние представляли собой комплекс физических и психологических переживаний, возникавших как реакция на окружающую действительность. Любая эмоция представляет собой результат ресурсного состояния человека, которое основано на совокупности физических и душевных сил. Социально-бытовые проблемы, несомненно, порождали «неодобряемые» для сообщества педагогов эмоции. Обитатели бараков представляли собой уникальное эмоциональное сообщество, в рамках которого уместными были эмоции неприязни, ненависти, зависти, злобы, отчаяния, апатии, безразличия и т. п. Даже так называемые учительские бараки не стали исключением. В бараках среди представителей городской интеллигенции широкое распространение имели классические негативные эмоции, иногда перераставшие во взаимные оскорбления, драки и воровство. Поводом к подобным эмоциональным проявлениям могли стать проблемы социально-бытового плана. В воспоминаниях зафиксированы случаи краж вязанок хвороста в учительских бараках, карандашей и тетрадей, споров из-за общей жилой площади, дежурств в общей кухне и коридоре и т. п. 
В делопроизводственной документации городского отдела народного образования, не подлежащей опубликованию, также содержатся многочисленные указания на неодобряемые эмоциональные реакции в среде педагогов города. Даже директора школ порой позволяли себе проявлять отчаяние или апатию. Некоторые высказывания руководителей образовательных учреждений города были не просто очень эмоционально окрашенными, они противоречили постулатам партии и государства периода культурной революции ${ }^{53}$.

Таким образом, повседневная жизнь учителей города Магнитогорска была насыщена комплексом социально-бытовых, личностных и профессиональных проблем. Ключевой особенностью функционирования эмоционального сообщества педагогов стало особое внимание государства к профессии учителя, который играет одну из важнейших ролей в процессе социализации. Составной частью кадровой политики государства являлось расширение и укрепление системы педагогического образования в стране. В Магнитогорске открылся учительский институт, что позволило решить проблему нехватки кадров в городе и обеспечить в будущем необходимое качество обучения. Комплекс эмоций, характерный для педагогического сообщества, оказался гораздо объемнее и разнообразнее, чем тот, который задавался эмоциональным режимом эпохи. Способы выражения эмоций, ожидаемые от учительства, были регламентированы и ориентировались прежде всего на сдержанность, дисциплинированность. Сам внешний образ учителя нес ощущение уверенности и спокойствия. Не поощрялась активная моторика, жестикуляция. Подобные характеристики стали типичными для эмоционального сообщества учителей города в рамках официального дискурса, но в целом педагогическое сообщество лишь отчасти соответствовало заданным требованиям. В реальной жизни наряду с активным присутствием вышеназванных признаков эмоционального сообщества педагогов имелись иные эмотивы, свойственные учителям города. Последние одновременно принадлежали к многим эмоциональным сообществам и, естественно, проявляли присущие этим сообществам эмоции. Эмоциональные состояния педагогов были разнообразными и в целом характерными для советских граждан в силу определенных мероприятий режима; эмоциональные репертуары определялись комплексом объективных и субъективных факторов, а эмоциональные переживания были как коллективистскими, так и индивидуальными.

1 Рожков А.Ю. Провинциальный город в ракурсе «эмоциональной» истории повседневности: исследовательские подходы и проблемы (Краснодар, 1920-е) // Вестник Краснодарского государственного института культуры. 2016. № 2 (6). URL: http://vestnikkguki.esrae.ru/ pdf/2016/2(6)/143.pdf (дата обращения: 23.03.2017).

2 См., напр.: Шахадат Ш. Психологизм, любовь, отвращение, разум: эмоции с точки зрения литературоведения // Российская империя чувств. Подходы к культурной истории эмоций. М., 2010. С.227-258; Alexopoulos G. Soviet Citizenship, More or Less: Righte, Emotions and States of Civic Belonging // Kritika: Explorations in Russian and Eurasian History. 2006. No. 3. P. 487-528; Plamper J. The History of Emotion: An Interview with William Reddy, Barbara Rozenwein, and Peter Stern // History and Theory. 2010. No.49. P. 237-265; Reddy W.: 1) Sentementalism and Its Erasure: The Role of Emotions in the Era of the French Revolution // Journal of Modern 
History. 2000. No.1. P. 109-152; 2) The Invisible Code: Honor and Santiment in Postrevolutionary France. Berkley, 1997; 3) The Navigation of Feeling: A Framework for the History of Emotions. Cambridge, 2001; Stearns P.N., Stearns C.Z. Emotionology: Clarifying the History of Emotions and Emotional Standards // The American Historical Review. 1985. Vol. 90, no. 4. P. 813-836; Юханнисон $K$. История меланхолии: о страхе, скуке и чувствительности в прежние времена и теперь. М., 2011; Февр Л. Чувствительность и история // Февр Л. Бои за историю. М., 1991. С. 109-125; Хльнина Т. П. «Писали и про войну, и тоску по дому»: дневники и письма военного времени как практики реализации приватного // Проблемы российской истории. 2013. № 1. С. 295-307; Юзефович Н.Г. Идеологизированный субстрат номинаций счастье и тоска в России предвоенного периода в статье Шейлы Фицпатрик // Политическая лингвистика. 2014. № 1 (47). С.279-283; Макарова Н. Н. Эмоциональный режим эпохи форсированной индустриализации (по материалам Магнитогорска) // Диалог со временем. 2017. № 60. С. 238-256.

3 Золотарев О.В.: 1) Народное образование в Коми автономии в 1918-1940 годах. Сыктывкар, 1993; 2) Советская школьная политика и ее осуществление в Коми автономии (1918-1941 гг.). Сыктывкар, 1998; 3) История народного образования в Республике Коми. Сыктывкар, 2002.

4 Васильковская Е.И.: 1) Важнейший этап становления советской школы (1930-1935) // Образование в современном мире: сб. науч. статей. Саратов, 2006. С. 19-26; 2) Особенности формирования и развития системы педагогического образования в Советском государстве в 1930 1940-е гг. // Вестник Саратовской государственной юридической академии. 2006. № 6. С. 81-86.

5 Юинг Т. Учителя эпохи сталинизма. М., 2011.

6 Холлс Л. Социальная история России 1917-1941. Ростов н/Д., 1994.

7 Fitzpatrick Sh.: 1) Education and Social Mobility in the Soviet Union 1921-1934. Cambrige, 1979; 2) New Perspectives on Stalinizm // Russian Review. 1986. Vol.45, no. 4. P. 357-373; Фицпатрик Ш. Повседневный сталинизм. Социальная история Советской России в 30-е годы. M., 2001.

8 O’Connor T.E. The Politics of Soviet Culture: Anatolii Lunacharskii. Ann Arbor, 1983.

9 Reddy W.M. The Navigation of Feeling... P. 200.

10 Ibid. P. 128.

11 Ibid. P. 129.

12 Rosenwein B. H. Emotional Communities in the Early Middle Ages. Ithaca, 2006.

13 Городской архив Магнитогорска (далее - ГА Магнитогорска). Ф. 12. Оп. 1а. Д. 1. Л. 8.

14 Там же. Л. 13.

15 Панова К.А. Наш любимый человек // Добрая память об учителе Магнитогорска. Магнитогорск, 1986. С. 28.

16 ГА Магнитогорска. Ф. 12. Оп. 1а. Д. 1. Л. 22.

17 Там же. Ф.4. Оп. 1. Д. 1. Л. 21.

18 Там же.

19 Там же.

20 Терехова А.С. И работали, и учились // Сборник воспоминаний ветеранов народного образования Магнитки. Магнитогорск, 1982. С. 12.

21 ГА Магнитогорска. Ф. 12. Оп. 1а. Д. 1. Л. 21, 33-34.

22 Эбулдина О.П. Хочется оглянуться на пройденный путь // Сборник воспоминаний ветеранов народного образования Магнитки. Магнитогорск, 1982. С.53.

23 Юдилевич - заведующий городским отделом народного образования в 1932-1933 гг.

24 ГА Магнитогорска. Ф. 12. Оп. 1а. Д. 1. Л.92.

25 Там же.

26 Там же. Л. 34.

27 ГА Магнитогорска. Ф. 10. Оп. 1. Д.9. Л. 22.

28 О ценах // Магнитогорский рабочий (Магнитогорск). 1934. 11 янв.

29 Государственный архив Российской Федерации (далее - ГАРФ). Ф.Р-7952. Оп.5. Д. 299.

30 Ильяшенко П.И. Среди сильных, мужественных, добрых людей // Сборник воспоминаний ветеранов народного образования Магнитки. Магнитогорск, 1982. С. 13. 
31 Будни учителя // Магнитогорский комсомолец (Магнитогорск). 1932. 23 июля.

32 ГАРФ. Ф.Р-7952. Оп. 5. Д. 297. Л. 33.

33 Воспоминания Л. Г. Чернопятовой. Записаны Н. Н. Макаровой в 2008 г. Личный архив автора.

34 Объединенный государственный архив Челябинской области (далее - ОГАЧО). Ф. 234. Оп. 1. Д. 216. Л. 50.

35 ГА Магнитогорска. Ф. 12. Оп. 1а. Д. 1. Л. 98 об.

36 Яворская E. K. Памятный год // Сборник воспоминаний ветеранов народного образования Магнитки. Магнитогорск, 1982. С.9-11.

37 Эбулдина О.П. Хочется оглянуться на пройденный путь. С. 55.

38 Stearns P.N., Stearns C.Z. Emotionology... P.813-836.

39 Юинг T. Учителя эпохи сталинизма.

40 Озерова Г.А. Свою судьбу связала я с Магниткой // Сборник воспоминаний ветеранов народного образования Магнитки. Магнитогорск, 1982. С. 19-20.

41 Воспоминания О.В. Быстровой. Записаны Н. Н. Макаровой в 2009 г. Личный архив автора.

42 Воспоминания Л. Г. Чернопятовой. Записаны Н. Н. Макаровой в 2009 г. Личный архив автора.

43 Кондратковская Н.Г. «Ах, если бы еще одну мне жизнь». Белорецк, 2006. С. 102.

44 Яворская E.К. Памятный год. С.9-12.

45 Озерова Г.А. Свою судьбу связала я с Магниткой. С. 20.

46 Приводится по: Plamper J. The History of Emotion... P. 247.

47 Акулина E.A. Мои воспоминания о Магнитке // Сборник воспоминаний ветеранов народного образования Магнитки. Магнитогорск, 1982. С. 16.

48 Кондратковская Н.Г. «Ах, если бы еще одну мне жизнь». С. 102.

49 Акулина E.A. Мои воспоминания о Магнитке. С. 16.

50 Воспоминания Чернопятовой...; Кондратковская Н.Г. «Ах, если бы еще одну мне жизнь». С. 104.

51 Воспоминания Н.А. Алешниковой. Записаны Н.Н. Макаровой в 2015 г. Личный архив автора.

52 Терехова А.С. И работали, и учились. С. 12.

53 ГА Магнитогорска. Ф. 10. Оп. 1. Д. 64. Л. 50.

Статья поступила в редакцию 12 января 2018 г. Рекомендована в печать 14 ноября 2019 г.

\section{ДЛЯ ЦИТИРОВАНИЯ}

Макарова Н.Н. Эмоциональное сообщество и повседневная жизнь учителей Магнитогорска (1929-1941 годы) // Новейшая история России. 2020. Т. 10, № 1. С. 168-182. https://doi.org/10.21638/11701/spbu24.2020.111 уДК 93/94 (908 / 930.1)

Аннотация: Проблематика истории повседневности и истории эмоций, крайне популярная в мировой, а в последнее время и в отечественной исторической науке, обращена к разнообразным историческим эпохам и территориям. Однако до сих пор отсутствует опыт изучения локального сообщества в контексте проблем повседневного существования и эмоционального репертуара в XX столетии. Средством преодоления дифференцированного изучения «повседневности» и «эмоциональности» может выступать анализ конкретных эмоциональных сообществ в определенных хронологических и территориальных границах. В статье осуществлена попытка рассмотреть учительство города Магнитогорска в период форсированной индустриализации как уникальное эмоциональное сообщество с особым типом повседневного существования. Исследование опирается на широкую источниковую базу, в том числе на ранее не опубликованные материалы. Преобладающим типом исторических источников стали воспоминания учителей города Магнитогорска, написанные в разные годы. Статья 
опирается на методологический инструментарий, предложенный Я. Плампером, У.Редди. Социальный портрет педагога в городе Магнитогорск далек от идеального образа учителя. Среди педагогов преобладали женщины в возрасте до 20 лет с минимальным стажем и уровнем образования, но официальный дискурс и воспоминания об учителях Магнитостроя рисовали эталонный образ советского педагога. Последний формировался из общечеловеческих, профессиональных характеристик и описания внешности учителя. Педагогическое сообщество Магнитостроя представляло собой сложный эмоциональный микромир, в котором сосуществовали разнообразные эмоциональные репертуары, а сами учителя одновременно принадлежали к различным эмоциональным сообществам, демонстрировавшим порой неодобряемые эмоциональные реакции. Социально-бытовые условия, общий уровень благоустройства жизни и труда учителей определяли ландшафты повседневности и черты господствовавшего эмоционального режима. Последний представлял собой официальную государственную идеологию, адаптированную к конкретным социокультурным и индивидуальным особенностям города, сообщества и человека.

Ключевые слова: история, повседневность, эмоции, эмоциональное сообщество, эмоциональный репертуар, Магнитогорск.

Сведения об авторе: Макарова Н.Н. - канд. ист. наук, доц., Магнитогорский государственный технический университет им. Г.И. Носова (Магнитогорск, Россия); makarovanadia@mail.ru

Магнитогорский государственный технический университет им. Г.И.Носова, Россия, 455000 , Магнитогорск, ул. Ленина, 38

\title{
FOR CITATION
}

Makarova N. N. 'Emotional Community and Everyday Life of the Teachers of Magnitogorsk (1929-1941)', Modern History of Russia, vol. 10, no. 1, 2020, pp. 168-182. https://doi.org/10.21638/11701/spbu24.2020.111

\begin{abstract}
Using a broad source base, including previously unpublished materials, this study examines teaching in Magnitogorsk in the period of accelerated industrialization as a unique emotional community with a special type of daily life.. The predominant historical sources are recollections of Magnitogorsk teachers, written at different times relative to the time of studied events. The article uses methodological tools proposed by lu. Bessmertny, H. R. lausom, J. Plamper, and W. Reddy. The social portrait of a Magnitogorsk teacher was far from ideal. Teachers were dominated by women under the age of 20 , with minimal experience and education, but official discourse and memories about teachers at Magnitostroi drew on a universal reference image of a professional Soviet teacher. The educational community at Magnitostroi was a complex emotional microcosm in which a variety of emotional repertoires coexisted, and teachers themselves belonged to different emotional communities that demonstrated sometimes unusual emotional reactions. Features of social conditions, the overall level of improvement of teachers' lives and work of teachers, defined the landscapes of everyday life and features of the dominant emotional regime. The last was an official state ideology, adapted to the specific sociocultural and individual peculiarities of city, community, and people.
\end{abstract}

Keywords: history, everyday life, emotions, emotional community, emotional repertoire, Magnitogorsk.

Author: Makarova N. N. - PhD, Associate Professor, Nosov Magnitogorsk State Technical University (Magnitogorsk, Russia); makarovanadia@mail.ru

Nosov Magnitogorsk State Technical University, 38, ul. Lenina, Magnitogorsk, 455000, Russia

\section{References:}

Akulina E. A. 'My memories of Magnitogorsk', Sbornik vospominanii veteranov narodnogo obrazovaniia Magnitki (Magnitogorsk, 1982). (In Russian)

Alexopoulos G. 'Soviet Citizenship, More or Less: Right, Emotions and States of Civic Belonging', Kritika: Explorations in Russian and Eurasian History, no. 3, 2006. DOI: 10.1353/kri.2006.0030.

Ebuldina O. P. 'I want to look back at the path traveled', Sbornik vospominanii veteranov narodnogo obrazovaniia Magnitki (Magnitogorsk, 1982). (In Russian) 
Ewing T. Teachers of the Stalinist era (Moscow, 2011). (Rus. Ed.)

Favre L. 'Sensitivity and history', Boi za istoriiu (Moscow, 1991). (In Russian)

Fitzpatrick S. Education and Social Mobility in the Soviet Union 1921-1934 (Cambridge, 1979). (Rus. Ed.)

Fitzpatrick S. Everyday Stalinism: the social history of Soviet Russia in the 30 years (Moscow, 2001). (Rus. Ed.)

Fitzpatrick S. 'New Perspectives on Stalinism', Russian Review, Vol.45, no.4, October, 1986. DOI: $10.2307 / 130466$

Holmes L. Social history of Russia 1917-1941 (Rostov-on-Don, 1994). (Rus. Ed.)

lliyashenko P.I. 'Among strong, courageous, kind people', Sbornik vospominanii veteranov narodnogo obrazovaniia Magnitki (Magnitogorsk, 1982). (In Russian)

Johannisson K. History of melancholy. About fear, boredom and sensitivity in the old days and now (Moscow, 2011). (Rus. Ed.)

Khlynina T.P. "'They wrote about the war, and homesick": the diaries and letters of wartime as the practice of private', Problemy rossiiskoi istorii, no. 1, 2013. (In Russian)

Kondratkovskaia N. G. "Oh, if only one more life for me" (Beloretsk, 2006). (In Russian)

Makarova N. N. 'Emotional regime of the era of forced industrialization (based on the materials of Magnitogorsk)', Dialog so vremenem, no. 60, 2017. (In Russian)

O'Connor T. E. The Politics of Soviet Culture: Anatolii Lunacharskii (Ann Arbor, 1983).

Ozerova G. A. 'I linked my fate with Magnitka', Sbornik vospominanii veteranov narodnogo obrazovaniia Magnitki (Magnitogorsk, 1982). (In Russian)

Panova K.A. 'Our favorite person', Dobraia pamiat' ob uchitele Magnitogorska (Magnitogorsk, 1986). (In Russian)

Plamper J. 'The History of Emotion: An Interview with William Reddy, Barbara Rozenwein, and Peter Stern', History and Theory, no. 49, 2010. DOI: 10.1111/j.1468-2303.2010.00541.x.

Reddy W. 'Sentementalism and Its Erasure: The Role of Emotions in the Era of the French Revolution', Journal of Modern History, no. 1, 2000. DOI: 10.1086/315931.

Reddy W. M. The Navigation of Feeling for the History of Emotions. (Cambridge, 2001).

Reddy W. The Invisible Code: Honor and Sentiment in Post Revolutionary France (Berkley, 1997).

Rosenwein B. H. Emotional Communities in the Early Middle Ages (Ithaca, 2006).

Rozhkov A. Yu. 'Provincial city in the perspective of the "emotional" history of everyday life: research approaches and problems (Krasnodar, 1920)', Vestnik Krasnodarskogo gosudarstvennogo instituta kul'tury, no. 2 (6), 2016. (In Russian)

Schahadat S. 'Psychologism, love, disgust, reason: emotions from the point of view of literary criticism', Rossiiskaia imperiia chuvstv. Podkhody k kulturnoi istorii emotsii (Moscow, 2010). (In Russian)

Stearns P.N., Stearns C.Z. 'Emotionology: Clarifying the History of Emotions and Emotional Standards', The American Historical Review, Vol. 90, no. 4, 1985.

Terekhova A. S. 'Both worked and studied', Sbornik vospominanii veteranov narodnogo obrazovaniia Magnitki (Magnitogorsk, 1982). (In Russian)

Vasilkovskaia E. I. 'Features of formation and development of system of pedagogical education in the Soviet state in the 1930s-1940s', Vestnik Saratovskoi gosudarstvennoi iuridicheskoiakademii, no. 6, 2006. (In Russian) Vasilkovskaia E.I. 'The most important stage of formation of the Soviet school (1930-1935)', Obrazovanie v sovremennom mire (Saratov, 2006). (In Russian)

Yavorskaya E.K. 'Memorable year', Sbornik vospominanii veteranov narodnogo obrazovaniia Magnitki (Magnitogorsk, 1982). (In Russian).

Yuzefovich N.G. 'Ideologized substrate of the nominations happiness and longing in Russia of the prewar period in the article by Sheila Fitzpatrick', Politicheskaia lingvistika, no. 1(47), 2014. (In Russian)

Zolotarev O.V. History of public education in the Komi Republic (Syktyvkar, 2002). (In Russian)

Zolotarev O. V. Public education in Komi autonomy in the 1940s (Syktyvkar, 1993). (In Russian)

Zolotarev O. V. Soviet school policy and its implementation in the Komi autonomy (1918-1941) (Syktyvkar, 1998). (In Russian)

Received: January 12, 2018

Accepted: November 14, 2019

Новейшая история России. 2020. Т. 10, № 1 